University of Nebraska - Lincoln

DigitalCommons@University of Nebraska - Lincoln

USDA National Wildlife Research Center - Staff Publications
U.S. Department of Agriculture: Animal and Plant Health Inspection Service

2021

\title{
Evaluating the effects of mountain beaver (Aplodontia rufa) management on conifer stocking in western Oregon
}

Jimmy D. Taylor

USDA APHIS Wildlife Services, jimmy.d.taylor@usda.gov

Vanessa M. Petro

Oregon State University, Vanessa.Petro@oregonstate.edu

Follow this and additional works at: https://digitalcommons.unl.edu/icwdm_usdanwrc

Part of the Natural Resources and Conservation Commons, Natural Resources Management and Policy Commons, Other Environmental Sciences Commons, Other Veterinary Medicine Commons, Population Biology Commons, Terrestrial and Aquatic Ecology Commons, Veterinary Infectious Diseases Commons, Veterinary Microbiology and Immunobiology Commons, Veterinary Preventive Medicine, Epidemiology, and Public Health Commons, and the Zoology Commons

Taylor, Jimmy D. and Petro, Vanessa M., "Evaluating the effects of mountain beaver (Aplodontia rufa) management on conifer stocking in western Oregon" (2021). USDA National Wildlife Research Center Staff Publications. 2417.

https://digitalcommons.unl.edu/icwdm_usdanwrc/2417

This Article is brought to you for free and open access by the U.S. Department of Agriculture: Animal and Plant Health Inspection Service at DigitalCommons@University of Nebraska - Lincoln. It has been accepted for inclusion in USDA National Wildlife Research Center - Staff Publications by an authorized administrator of DigitalCommons@University of Nebraska - Lincoln. 


\title{
Evaluating the effects of mountain beaver (Aplodontia rufa) management on conifer stocking in western Oregon
}

\author{
Jimmy D. Taylor ${ }^{\mathrm{a}, *}$, Vanessa M. Petro ${ }^{\mathrm{b}}$ \\ ${ }^{\text {a }}$ USDA, APHIS, Wildlife Services, National Wildlife Research Center, 321 Richardson Hall, Corvallis, OR, 97331, USA \\ ${ }^{\mathrm{b}}$ Department of Forest Ecosystems and Society, Oregon State University, 321 Richardson Hall, Corvallis, OR, 97331, USA
}

\section{A R T I C L E I N F O}

\section{Keywords:}

Browse

Clipping

Damage

Interplanting

Regeneration

Seedling

Toxicant

Trapping

Vertebrate pests

\begin{abstract}
A B S T R A C T
Mountain beaver (Aplodontia rufa) is the most primitive rodent species in North America and is endemic to the Pacific Northwest, USA. Within their range, mountain beaver cause more conflict with conifer forest regeneration than any other vertebrate species. Most damage occurs as a result of clipping and browsing new seedlings, which reduces stocking density and delays stand development. An integrated approach using trapping and a registered toxicant (baiting) has been suggested as the most efficacious means to reduce seedling loss during stand initiation. We evaluated this management strategy in intensively managed conifer stands across two mountain ranges in western Oregon. Harvest units were divided equally and management (trapping and baiting) was implemented on a randomly selected half of each unit; the remaining halves served as an experimental control. We conducted damage assessments in fixed 0.04 ha circular plots at approximate 1, 6, and 12 month intervals after planting and initiation of management activities. After 12 months, we observed mountain beaver damage in $100 \%$ of control plots and $95 \%$ of treatment plots; however, there was a 79\% decrease in the estimated odds of damage for plots where trapping and baiting was implemented (95\% CI 43-92). Mean seedling height was $10.6 \mathrm{~cm}$ taller in treated plots than control plots 1 year post-planting (95\% CI 4.1-17.1). Reoccupation of vacant burrows began within 1 month; within 12 months, only 5\% of trapped plots remained unoccupied. Reported costs and benefits varied among harvest units, but management was less expensive $(\$ 154.09 / \mathrm{ha})$ than the cost of interplanting gaps created by mountain beaver damage $(\$ 182.13 / \mathrm{ha})$. Although trapping and baiting may not offer a one-time solution to damage problems, it is an effective tool in reducing damage, saving management costs, and meeting compliance with forest regulations and certification requirements.
\end{abstract}

\section{Introduction}

Mountain beaver (Aplodontia rufa) are semi-fossorial rodents endemic to the humid, wet forests and steep mountain areas of the Pacific Northwest (Arjo, 2007). They are among a variety of herbivores that inhibit conifer seedling growth or cause mortality that leads to forest regeneration delays and understocked plantations (Black and Lawrence, 1992; Cafferata, 1992). Mountain beaver are therefore managed as vertebrate pests on private industrial forestlands and are of economic concern because of the damage they cause to western conifers, predominately Douglas-fir (Pseudotsuga menziesii), in northern California, western Oregon, and western Washington (Borrecco and Anderson, 1980; Campbell and Evans, 1988). Economic loss is most severe during stand initiation when conifer seedlings are stocked at high densities and site preparation practices reduce competing vegetation and availability of mountain beaver forage (Borrecco and Anderson, 1980; Cafferata, 1992). Mountain beaver forage in patterns consistent with central place foraging theory (Orians and Pearson, 1979) which results in tree damage centered on their burrow entrance. As seedlings are removed, patches of damage grow larger (Neal and Borrecco, 1981), resulting in a clumped distribution of damage throughout regenerating stands (Cafferata, 1992). Low stocking densities as a result of mountain beaver and other wildlife damage may lead to noncompliance with forest regulations, certification requirements, or landowner objectives. Excessive damage requires managers to send planting crews back to stands in order to fill unwanted gaps, commonly referred to as interplanting (Crouch, 1969).

Integrated management plans are commonly used to reduce mountain beaver damage. In Oregon, lethal body gripping traps are used to quickly dispatch mountain beavers in regenerating stands. This is generally the most effective method for reducing damage (Cafferata,

\footnotetext{
* Corresponding author. National Wildlife Research Center USDA, APHIS, Wildlife Services 321 Richardson Hall, Corvallis, Oregon, 97331, USA.

E-mail address: jimmy.d.taylor@usda.gov (J.D. Taylor).
} 
1992); however, reinvasion can be rapid (Hacker and Coblentz, 1993; Arjo et al., 2007). The toxicant Rozol ${ }^{\circledR}$ (active ingredient chlorophacinone) is an alternative lethal tool (hereafter, baiting) available to reduce mountain beaver damage in Washington and Oregon; however, it is intended to be used in conjunction with trapping (Arjo et al., 2009), not as a stand-alone. Non-lethal approaches to mountain beaver damage have included the use of individual barriers for protecting seedlings, but seedling loss was shown to be as much as $56 \%$ in captive trials using this form of protection (Runde et al., 2008).

In western Washington, mountain beaver density increased following timber harvest and mountain beaver survival was not affected by timber harvest or chemical site preparation (Arjo, 2010). Arjo et al. (2009) found one integrated pest management program for mountain beaver to be more cost efficient than another in Washington, yet seedling damage did not differ between alternatives. We found no additional research studies that contrasted a trapping and baiting program with an experimental control (i.e., no management). More so, we found no research that evaluated mountain beaver damage to seedlings within the first year after planting. In order to quantify the benefits of trapping and baiting to reduce mountain beaver damage in Oregon, we conducted this novel observational study of operational practices to contrast seedling damage in areas that received integrated management (trapping and baiting) to those that did not. We hypothesized 1 year after planting that 1) mountain beaver from adjacent mixed aged stands would reoccupy trapped burrows, 2) mountain beaver damage to seedlings would be greater in control plots than treatment plots, and 3) seedling heights would be greater in treatment plots than control plots. This study was conducted in accordance with USDA National Wildlife Research Center protocol QA-2232.

\section{Materials and methods}

\subsection{Study area}

We conducted our study using 5 forest harvest units (size 10-44 ha) in the Coastal and Cascade Mountain Ranges of western Oregon, USA (Fig. 1). Elevation ranged from 330 to 675 m.a.s.l. for the coastal sites (Lincoln County) and 320-540 m.a.s.l. in the Cascades (Linn County).

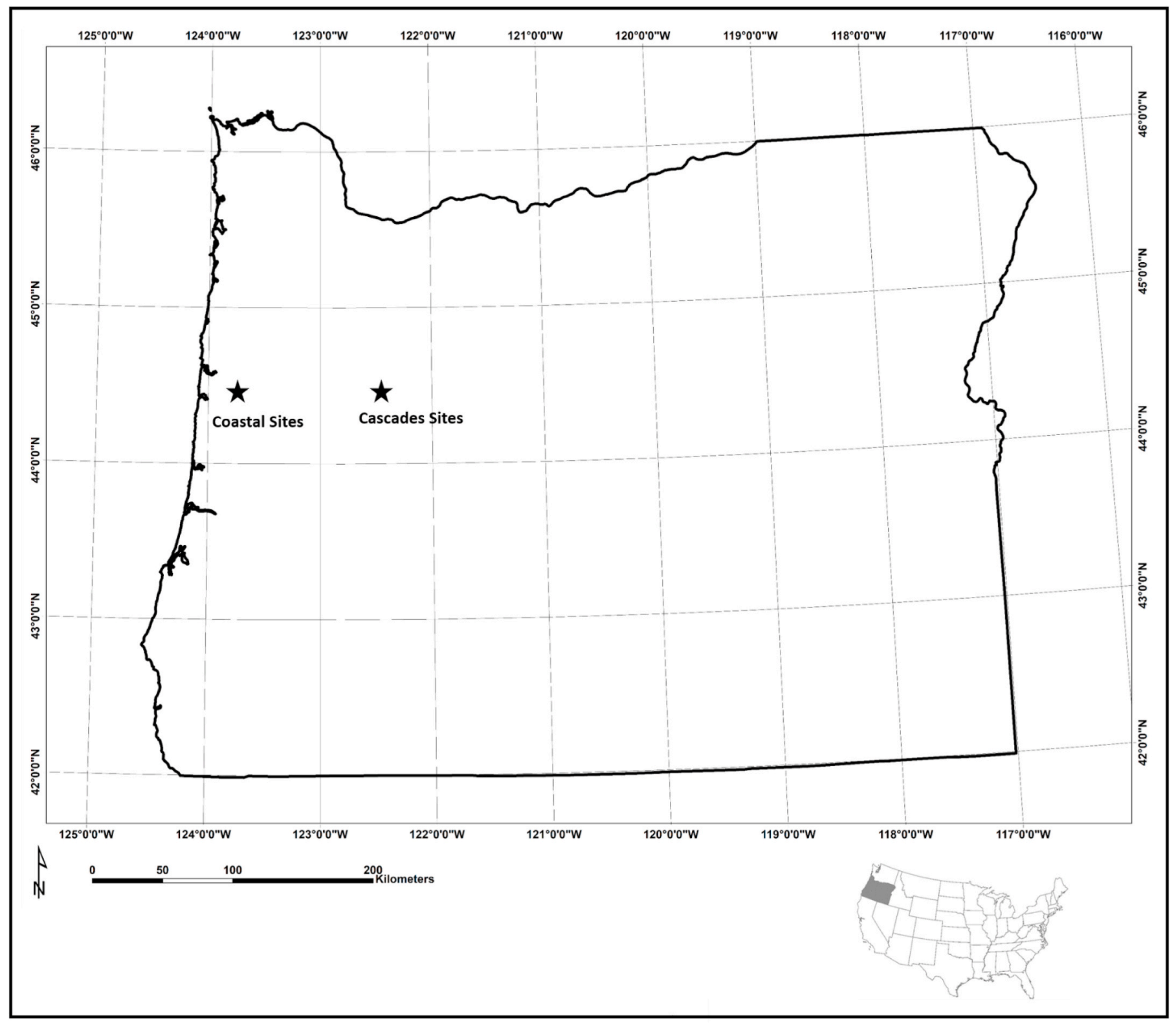

Fig. 1. Locations of study sites used for mountain beaver trapping effects study in western Oregon, USA, 2014-2015. 
For Coastal sites, average annual temperature was $13{ }^{\circ} \mathrm{C}$ with total annual precipitation of $208 \mathrm{~cm}$, which mostly occurred as rain during the winter. Average annual temperature at the Cascade sites was $17{ }^{\circ} \mathrm{C}$ with total annual precipitation of $274 \mathrm{~cm}$, and snow comprising a larger portion of precipitation during the winter (National Oceanic and Atmospheric Administration 2015). Harvest units were primarily composed of Douglas-fir with intermittent western hemlock (Tsuga heterophylla), spruce (Picea spp.), and hardwood species prior to harvest. Surrounding forested habitat was characterized by a matrix of regenerating even and uneven aged conifer dominated stands. All harvest units were clearcut in 2013 and received standard site preparation including aerial herbicide applications for vegetation control, slashing shrub species, and burning of brush piles at log decks and landing sites. All harvest units were replanted between January and February of 2014. We did not ask landowners to change their operations for this study with the exception of leaving one half of each harvest unit untreated as experimental controls. Average stocking density across plantations was 957 seedlings/ha and managers used combinations of bareroot and containerized seedlings obtained from nurseries (Table 1 ). All managers used lethal trapping during planting in combination with $\operatorname{Rozol}{ }^{\circledR}$ as an integrated approach to damage management (Arjo et al., 2009).

\subsection{Experimental design}

We used a repeated measures design to quantify mountain beaver damage, although we used only the final measurements taken at the end of the study to test hypotheses 2 and 3. Each harvest unit served as a replicate ( 5 total) and was divided into approximate halves with similar topography. We then randomly selected the side that would receive trapping and baiting (i.e., treatment half). The remaining half of each harvest unit served as the experimental control. We identified the distribution of active mountain beaver burrow systems throughout each harvest unit prior to animal removal based on signs of haystacks or rock piling at burrow entrances, runways, foraging activity, and recent burrow excavations (Taylor et al., 2013). We assumed active burrow systems were occupied independent of each other because mountain beaver are a solitary species and nest (or den) individually (Borrecco and Anderson, 1980; Arjo, 2007). The central point of activity for each borrow system was recorded with a handheld global positioning system to establish sampling plots. Active burrows were randomly selected for damage monitoring if more than 10 were located per harvest unit. We established a fixed 0.04 ha circular plot around the center of each active burrow selected for the study. Each harvest unit had a minimum of 10 total plots or a maximum of 20 . We established a total of 80 plots ( 40 treated, 40 control) across 5 harvest units.

\subsection{Damage monitoring}

Wildlife damage management activities occurred during tree planting at all harvest units. Forest managers reported they removed a total of 249 mountain beaver from treatment plots with Conibear \#110 body grip traps (Table 1). We assumed equal experience between trapping crews. Trapping consisted of 3 rounds of trap checks followed by an application of Rozol ${ }^{\circledR}$ in each burrow, per label instructions, at the final trap check. The number of individuals trapped/harvest unit ranged from 18 to 103 , and catch per unit effort ranged from 0.007 to 0.027 (Table 1). We recorded mountain beaver damage in each 0.04 ha plot within both treatment and control halves of harvest units. Observations were repeated on all harvest units at 1, 6, and 12 month intervals after planting from February 2014 through February 2015. Planted seedlings were identified to species and total height was measured to the nearest $\mathrm{cm}$ during each survey. Mountain beaver damage was identified by the appearance of a sharp $45^{\circ}$ edge near the base of seedlings or the clean removal of lateral or terminal leaders (Taylor et al., 2013). It is common for mountain beaver to clip entire seedlings near the base of the main stem and move them underground. Bases of stems clipped at sharp $45^{\circ}$ confirm mountain beaver damage, yet many short bases were subsequently covered by debris or new vegetation. Therefore, we assumed all missing seedlings were removed by mountain beaver. We also noted deer (Odocoileus hemionus columbianus) and elk (Cervus canadensis) browse based on the appearance of frayed ends or "tearing" at terminal and lateral branches, and complete uprooting of seedlings by elk. Seedlings found pulled from the ground with roots intact were classified as ungulate damage, caused by elk. We separated damage caused by ungulates and mountain beaver, and assumed ungulate browse within harvest units would be similar between treatment and control plots. Given the solitary behavior of mountain beaver (Arjo, 2007), we noted reoccupation within treatment plots when mountain beaver activity resumed at a burrow system after an individual was removed.

In order to better understand the costs and potential benefits of integrated mountain beaver management, we asked foresters to report costs associated with trapping and baiting, and interplanting gaps caused by mountain beaver damage. We acknowledge these are selfreported estimates and realize there are likely different costs for materials and services between ownerships (e.g., nursery costs, internal personnel vs. contractors, etc.). Our goal was to identify possible differences between treatment and control, and to contrast our small scale estimates with similar estimates at a regional scale.

\subsection{Data analyses}

We calculated damage frequency (number of damaged plots) and

Table 1

Characteristics of forest harvest units used to evaluate the effects of mountain beaver (MB) trapping in Oregon, USA 2014-2015.

\begin{tabular}{|c|c|c|c|c|c|c|}
\hline Description & Variable & Good Luck & Southern Bull & Bull Run & South Peter & NP450 \\
\hline \multirow[t]{2}{*}{ Site } & Total size (ha) & 10.1 & 23.5 & 25.5 & 44.1 & 12.5 \\
\hline & Elevation (m.a.s.l.) & $460-550$ & $475-675$ & $330-625$ & $320-540$ & $345-410$ \\
\hline \multirow[t]{3}{*}{ Planting } & Plant date & June 2, 2014 & $2 / 17 / 2014$ & $2 / 13 / 2014$ & $2 / 21 / 2014$ & $1 / 29 / 2014$ \\
\hline & Seedlings/ha & 773 & 946 & 944 & 1062 & 1062 \\
\hline & Stock type ${ }^{a}$ & $\mathrm{P}+1, \mathrm{~S}-8, \mathrm{P}-4 \mathrm{X} 4$ & $\begin{array}{l}\mathrm{P}+1, \mathrm{~S}-8 \\
\mathrm{P}-4 \mathrm{X} 4\end{array}$ & $\begin{array}{l}\mathrm{P}+1, \mathrm{~S}-8 \\
\mathrm{P}-4 \mathrm{X} 4\end{array}$ & $1+1, \mathrm{P}+1$ & $\mathrm{P}+1, \mathrm{~S}-15$ \\
\hline \multirow[t]{5}{*}{ Trapping } & Effort (days) & 29 & 29 & 29 & 31 & 31 \\
\hline & MB taken (\#) & 39 & 103 & 55 & 34 & 18 \\
\hline & MB taken/ha & 7.7 & 8.8 & 4.3 & 1.5 & 2.9 \\
\hline & Traps (\#) & 69 & 190 & 70 & 141 & 47 \\
\hline & Catch/Unit Effort & 0.019 & 0.018 & 0.027 & 0.007 & 0.012 \\
\hline \multirow[t]{2}{*}{ Costs } & Trapping and baiting ${ }^{\mathrm{b}}$ & $\$ 250.42$ & $\$ 190.84$ & $\$ 107.49$ & $\$ 100.07$ & $\$ 121.61$ \\
\hline & Interplanting $^{c}$ & $\$ 351.84$ & $\$ 172.61$ & $\$ 225.00$ & $\$ 124.17$ & $\$ 37.01$ \\
\hline
\end{tabular}

${ }^{\text {a }}$ S-8, S-15, and P-4X 4 are containerized seedlings grown in nurseries for a year; $\mathrm{P}+1$ are grown is containers for 1 year, then transferred to nursery beds for a second year; $1+1$ are bareroot seedlings grown for 1 year in a seed bed, then transplanted and grown for a second year in a nursery bed.

b Price per hectare costs reported by foresters for trapping and baiting in treated sites, adjusted for inflation to 2020 \$USD.

c Price per hectare costs reported by foresters to interplant seedlings in control sites, adjusted for inflation to 2020 \$USD. 
damage intensity (proportion of damaged trees within plots) between treated and control areas for each time interval. To evaluate our first hypothesis, we inferred reoccupation of treated plots if damage frequency increased between intervals.

To test our second hypothesis, we used a generalized linear mixed model with a binomial distribution and logit link function to determine if mountain beaver damage differed between treatment and control plots. The response variable represented the counted proportion of mountain beaver damaged seedlings for each plot 12 months after planting. We incorporated treatment as a categorical fixed effect with control plots serving as the reference class. For the random effects model structure, we nested unit halves within harvest unit and included a separate observation-level random effect.

To test our final hypothesis, we used a linear mixed model to determine if seedling heights differed between treatment and control plots. The response variable represented individual seedling heights measured at each plot 12 months after planting. Treatment was included as a categorical fixed effect with control plots representing the reference class. We nested plots within unit halves within harvest units for the random effects structure. Likelihood-ratio chi-squared tests were used to assess goodness of fit between nested models. We reported the comparison between plot types for each model to contrast how mountain beaver damage and seedling heights differ. All statistical analyses were performed using the R statistical software program (version 3.6.1; www. r-project.org, accessed December 14, 2020).

\section{Results}

We conducted repeated observations of 2537 conifer seedlings across 40 treatment and 40 control plots for the 3 separate time intervals. The number of seedlings monitored/plot ranged from 15 to 47 due to variations in landowner stocking rates and physical site conditions (e.g., slash piles, rock outcroppings, and dense shrubs). Most seedlings surveyed were Douglas-fir (99\%), the remainder were western redcedar (Thuja plicata).

Mountain beaver damage consisted of lateral and terminal browsing in addition to clipping of entire seedlings near the stem base (i.e., missing). Seedlings classified as missing were noted more often in control plots (53\%) than treatment plots (25\%). One year after planting, the mean percentage of seedlings damaged by mountain beaver across all plots was 59\% (range 0-100). Mountain beaver damage to seedlings was detected in $100 \%$ of control plots and $95 \%$ of treatment plots. Overall, $46 \%$ and $76 \%$ of seedlings were damaged by mountain beaver in treatment and control plots, respectively. Mountain beaver damage continued over time in most harvest units (Table 2). We observed an initial lag in mountain beaver damage in treatment plots with the greatest rate of damage occurring between 6 and 12 months (Table 2), a time period in which most treatment plots were reoccupied by mountain beaver from adjacent untreated burrow systems (Hypothesis 1; Table 3).

Our study found support of a difference in mountain beaver damage

Table 2

Mean (SE) proportions of seedlings damaged by mountain beaver within treatment and control plots at 1,6 , and 12 month intervals after planting in western Oregon, USA, 2014-2015.

\begin{tabular}{|c|c|c|c|c|c|c|}
\hline \multirow{4}{*}{$\begin{array}{l}\text { Harvest } \\
\text { Unit }\end{array}$} & \multirow{2}{*}{\multicolumn{3}{|c|}{$\begin{array}{l}\text { Control Plots } \\
\text { Months Since Planting }\end{array}$}} & \multirow{2}{*}{\multicolumn{3}{|c|}{$\begin{array}{l}\text { Treatment Plots } \\
\text { Months Since Planting }\end{array}$}} \\
\hline & & & & & & \\
\hline & 1 & 6 & 12 & 1 & 6 & 12 \\
\hline & Month & Months & Months & Month & Months & Months \\
\hline NP450 & $1(1)$ & $36(2)$ & $43(15)$ & $1(0)$ & $31(9)$ & 64 (14) \\
\hline South Peter & $40(5)$ & $66(5)$ & $81(3)$ & $16(7)$ & $31(10)$ & $59(10)$ \\
\hline Good Luck & $30(5)$ & $76(9)$ & $82(8)$ & $3(2)$ & $28(9)$ & 46 (13) \\
\hline Bull Run & $22(4)$ & $72(10)$ & $73(7)$ & $1(1)$ & $19(5)$ & $26(7)$ \\
\hline $\begin{array}{l}\text { Southern } \\
\text { Bull }\end{array}$ & $25(4)$ & $77(6)$ & $77(6)$ & $4(2)$ & $30(7)$ & $41(7)$ \\
\hline
\end{tabular}

Table 3

Cumulative summary of treatment plots that were reoccupied by mountain beaver at 1,6 , and 12 month intervals after planting in western Oregon, USA, 2014-2015.

\begin{tabular}{|c|c|c|c|c|}
\hline \multirow[b]{2}{*}{ Harvest Unit } & \multirow[b]{2}{*}{ Treated Plots (\#) } & \multicolumn{3}{|c|}{ Plots Reoccupied (\#) } \\
\hline & & 1 Month & 6 Months & 12 Months \\
\hline NP450 & 5 & 1 & 5 & 5 \\
\hline South Peter & 10 & 5 & 8 & 9 \\
\hline Good Luck & 5 & 3 & 4 & 5 \\
\hline Bull Run & 10 & 3 & 9 & 9 \\
\hline Southern Bull & 10 & 4 & 10 & 10 \\
\hline Total & 40 & $16(40 \%)$ & $36(90 \%)$ & $38(95 \%)$ \\
\hline
\end{tabular}

between control and treatment plots 1 year after planting $\left(\chi^{2}{ }_{1}=7.51, p\right.$ $<0.001)$. There was a $79 \%$ decrease in the estimated odds of damage in plots where trapping and baiting occurred (Hypothesis 2; 95\% CI: 43-92). We also found support of a difference in mean seedling heights between control and treatment plots 1 year after planting $\left(\chi^{2}{ }_{1}=10.52\right.$, $\mathrm{p}<0.001$ ). Mean seedling heights for treated plots were $10.6 \mathrm{~cm}$ taller than control plots (Hypothesis 3; 95\% CI 4.1-17.1).

Ungulates damaged approximately $15 \%$ of seedlings across all harvest units, and proportions were similar between trapped (17\%) and untrapped (13\%) plots. We excluded seedlings damaged by ungulates in our analyses unless seedlings also were damaged by mountain beaver. Most ungulate damage was light browsing of terminal and lateral stems. We noted only 15 occasions where seedlings were uprooted, presumably by elk. Most of them were pulled between planting and the first damage assessment at 1 month. Approximately half (7/15) of pulled seedlings occurred within a single plot.

\section{Discussion}

Mountain beaver fill a biological niche and possess intrinsic value as a native animal to the Pacific Northwest (Steele, 1986; Arjo, 2007), yet their damage to industrial forestlands often exceeds acceptable levels of tolerance. Historical methods to reduce mountain beaver damage included managing mountain beaver populations, or reducing mountain beaver density by setting 50-62 traps/ha (Cafferata, 1992). It is important to note that the integrated trapping-baiting activities we reported in this study were not to manage mountain beaver populations, rather they were an example of reducing human-wildlife conflict, or wildlife damage management (Conover, 2002). Number of traps/ha in this study ranged from 6 to 16, and traps were only set in burrows that were immediately surrounded by newly planted seedlings.

Mountain beaver damage to seedlings is clustered in distribution, creating non-stocked patches in stands rather than random mortality (Cafferata, 1992). This is largely due to their central place foraging behavior. Results from our study demonstrated that trapping reduced the amount of non-stocked patches compared to untrapped areas in the first year of stand initiation, as seen by the greater frequency and intensity of mountain beaver damage in untrapped plots. In Washington, Borrecco and Anderson (1980) found 30\% of seedlings were damaged within 1 year following planting. Another Washington study found up to $40 \%$ of seedlings were damaged by mountain beavers during the first 6 months after planting where lethal trapping did not occur until the following year (Arjo, 2010). Damage levels in both these studies were considered excessive and were less than our reported overall proportion of seedlings damaged by mountain beaver (76\%) in control plots.

Our study revealed that mean height of seedlings in control plots were shorter than treated plots 1 year after planting. Borrecco and Anderson (1980) found similar results in western Washington by comparing mean heights of clipped and undamaged seedlings. They suggested the damage from mountain beaver resulted in a 2-year height loss (Borrecco and Anderson, 1980). Both seedling mortality and suppressed vertical growth affect stocking density, meeting silvicultural 
benchmarks, and compliance with forest practices legislation. For example, the Oregon Forest Practices Act (ORS, 2020) requires harvested stands to be replanted within 2 years, and that young trees reach "free to grow" conditions within 6 years of harvest. Based on site productivity, a minimum of 100-200 trees per acr must survive following replanting (ORS, 2020), and the trees must be vigorous, well distributed, and advancing in forest succession. In our study, forest managers interplanted seedlings at least once per harvest unit to fill gaps created by mountain beaver within the first year following initial planting. In western Oregon, the average cost per acre to interplant is approximately 4 times the cost of mountain beaver control (K. Williams, Oregon Forest Industries Council, personal communication). Mean reported cost to prevent damage through trapping and baiting in our study was $\$ 154.09 /$ ha and was less than the mean cost of $\$ 182.13 /$ ha to interplant gaps where damage occurred (Table 1).

Wildlife damage to trees generally decreases when seedlings transition to saplings, which coincides with free to grow conditions. Mountain beaver have been shown to clip seedlings $\leq 19 \mathrm{~mm}$ ( $0.75 \mathrm{in})$ in diameter, causing seedling mortality up to 4 years after planting (Herlocker, 1950; Lawrence et al., 1961). Thus, increasing tree biomass and height as fast as possible has multiple advantages and potential cost savings. Borrecco and Anderson (1980) suggested that conifer seedling size, as a result of age at planting, affected the severity of damage by mountain beaver. Although our study did not assess differences in seedling stock types, we documented what foresters planted. Plug +1 and $1+1$ seedlings were taller and had larger diameters than others such as Styro-8 (S-8), although no seedlings in our study were as large as the 2-1 (3yo) seedlings evaluated by Borrecco and Anderson (1980). While it is possible that seedling age may have influenced foraging choices by mountain beaver in our study, we were not able to evaluate that potential effect.

Mountain beaver reoccupation occurred across all treated units and influenced the number of damaged seedlings at these locations. Mountain beaver typically disperse in winter and actively search for food because preferred forage species are unavailable (Arjo et al., 2007). Thus, vacant burrows may have been reoccupied quickly after individuals were removed through trapping. The first invaders may have succumbed to the toxicant packet left in each vacant burrow, thus extending protection for seedlings. However, the almost complete reoccupation of burrows after 12 months suggests the effects of the integrated approach are short-lived and burrows may be reoccupied multiple times with 1 year. Arjo and Nolte (2006) noted mountain beaver populations returned to pre-harvest levels 2 years after harvest, and Hacker (1992) found no statistical difference in mountain beaver densities 1 year after trapping between plantations that were trapped and untrapped. Despite the close proximity of treated and untreated areas within harvest units, previous research has suggested habitat features are more important in determining recolonization of sites than geographic proximity (Hacker and Coblentz, 1993). Recolonization may be more likely in areas where neighboring forested stands are younger (5-15 yo) while stands that contain a larger component of older, large diameter trees are less likely to contribute sources of individuals to recolonize unoccupied burrows (Arjo et al., 2007). The majority of our harvest units were bordered by stands of mixed ages; one harvest unit was entirely surrounded by stands $<15$ yo. Trapping buffers $\geq 300$ feet around harvest units may reduce reoccupation; however, this has not been accepted as a viable operation practice by forest industry (Cafferata, 1992).

In summary, perceived and realized impacts of mountain beaver damage to forest operations are largely related to economics. Costs associated with silviculture and damage management are highly variable, and many of these costs are proprietary. In practice, timber companies should evaluate costs and benefits of management activities to reduce mountain beaver damage at local and regional scales. Our study demonstrated that the integrated proactive approach of trapping and baiting was less expensive overall than the reactive approach of interplanting gaps created by mountain beaver, although we witnessed slightly more cost to manage than interplant on 2 of 5 sites. It is likely that follow-up treatments of trapping and baiting would minimize damage as burrows are reoccupied, although foresters should evaluate the additional costs and potential benefits until stands meet free to grow status. We also recommend that foresters further evaluate stock type choice when developing their integrated management plans to reduce mountain beaver damage. The additional costs of producing, storing, and handling older stock should be considered in the evaluation; as should the cost of interplanting larger seedlings if stocking levels are not maintained.

\section{CRediT authorship contribution statement}

Jimmy D. Taylor: Conceptualization, Methodology, Investigation, Data curation, Writing - original draft, Writing - review \& editing, Visualization, Supervision, Resources, Project administration, Funding acquisition. Vanessa M. Petro: Methodology, Investigation, Software, Formal analysis, Writing - original draft, Writing - review \& editing.

\section{Declaration of competing interest}

The authors declare that they have no known competing financial interests or personal relationships that could have appeared to influence the work reported in this paper.

\section{Acknowledgements}

Mention of commercial products or companies does not represent an endorsement by the U.S. Government. This research was supported by the Oregon Forest Industries Council and the USDA National Wildlife Research Center. We would like to thank the cooperating private industrial landowners for providing access to study sites and trapping data. We greatly appreciate the statistical support provided by A. Muldoon. We also thank E. Anderson, E. Beuttenmuller, J. King, L. Kline, and K. Tibbals for their assistance with data collection.

\section{References}

Arjo, W.M., Nolte, D.L., 2006. Boomer or bust: managing a Pacific Northwest pest species. Vertebrate Pest Conference 22, 181-186.

Arjo, W.M., 2007. Mountain beaver: a primitive fossorial rodent. In: Begall, S., Burda, H., Schleich, C.E. (Eds.), Subterranean Rodents: News from Underground. SpringerVerlag, Berlin, pp. 309-321.

Arjo, W.M., Huenefeld, R.E., Nolte, D.L., 2007. Mountain beaver home ranges, habitat use, and population dynamics in recently harvested plantations. Can. J. Zool. 85, 328-337.

Arjo, W.M., Shwiff, S., Kirkpatrick, K., 2009. Short-term evaluation of two integrated pest management programs for mountain beaver (Aplodontia rufa) control. Crop Protect. 28, 703-709.

Arjo, W., 2010. The effects of forestry site preparation on mountain beaver demographics and associated damage to tree seedlings. West. J. Appl. For. 25, 127-135.

Black, H.C., Lawrence, W.H., 1992. Animal damage management in Pacific Northwest forests: 1900-1990. In: Black, H.G. (Ed.), Silvicultural Approaches to Animal Damage Management in Pacific Northwest Forests. USDA FS Technical Report PNWGTR-287, pp. 23-55.

Borrecco, J.E., Anderson, R.J., 1980. Mountain beaver problems in the forests of California, Oregon, and Washington. Vertebrate Pest Conference 10, 135-142.

Cafferata, S., 1992. Silvicultural methods in relation to selected wildlife species. In: Black, H.G. (Ed.), Silvicultural Approaches to Animal Damage Management in Pacific Northwest Forests. USDA FS Technical Report PNWGTR-287, pp. 231-235.

Campbell, D.L., Evans, J., 1988. Recent approaches to controlling mountain beavers (Aplodontia rufa) in Pacific Northwest Forests. Vertebrate Pest Conference 13, 183-187.

Conover, M.R., 2002. Resolving Human-Wildlife Conflicts: the Science of Wildlife Damage Management. CRC Press, Boca Raton, Florida, USA.

Crouch, G.L., 1969. Animal Damage to Conifers on National Forests in the Pacific Northwest Region, vol. 28. USDA FS Resource Bulletin PNW, Portland, Oregon, p. 13.

Hacker, A.L., 1992. Population Attributes and Habitat Selection of Recolonizing Mountain Beaver. M.S. Thesis, Oregon State University, Corvallis, Oregon, p. 63.

Hacker, A.L., Coblentz, B.E., 1993. Habitat selection by mountain beavers recolonizing Oregon Coast Range clearcuts. J. Wildl. Manag. 57, 847-853.

Herlocker, E., 1950. Mountain beaver, biological curiosity. Audubon 52, 387-390. 
Lawrence, W.H., Kverno, N.B., Hartwell, H.D., 1961. Guide to Wildlife Feeding Injuries on Conifers in the Pacific Northwest. Western Forest Conservation Association, Portland, Oregon, p. 44.

Neal, F.D., Borrecco, J.E., 1981. Distribution and relationship of mountain beaver to openings in sapling stands. Northwest Sci. 55, 79-86.

Oregon Revised Statutes (ORS), 2020. The Oregon Forest Practices Act, 14, pp. 527-992 (Chapter 527), Section 527.610.

Orians, G.H., Pearson, N.E., 1979. On the theory of central place foraging. In: Horn, D.J., Stairs, G.R., Mitchell, R.D. (Eds.), Analysis of Ecological Systems. Ohio State University Press, Columbus, Ohio, pp. 155-177.
Runde, D.E., Nolte, D.L., Arjo, W.M., Pitt, W.C., 2008. Efficacy of individual barriers to prevent damage to Douglas-fir seedlings by captive mountain beavers. West. J. Appl. For. 23, 99-105.

Steele, D.T., 1986. The Mountain Beaver in California. MS thesis, UC Davis, Davis, California.

Taylor, J., Sphar, D., Ahrens, G., 2013. Identifying and Managing Mountain Beaver Damage to Forest Resources. Oregon State University Extension Publication EM9063. 